University of Nebraska - Lincoln

DigitalCommons@University of Nebraska - Lincoln

Agronomy \& Horticulture -- Faculty Publications

Agronomy and Horticulture Department

2003

Registration of RN582 Sorghum Germplasm Line

J. F. Pedersen

USDA-ARS

J. J. Toy

USDA-ARS, John.Toy@ars.usda.gov

Follow this and additional works at: https://digitalcommons.unl.edu/agronomyfacpub

Part of the Agricultural Science Commons, Agriculture Commons, Agronomy and Crop Sciences Commons, Botany Commons, Horticulture Commons, Other Plant Sciences Commons, and the Plant Biology Commons

Pedersen, J. F. and Toy, J. J., "Registration of RN582 Sorghum Germplasm Line" (2003). Agronomy \& Horticulture -- Faculty Publications. 1070.

https://digitalcommons.unl.edu/agronomyfacpub/1070

This Article is brought to you for free and open access by the Agronomy and Horticulture Department at DigitalCommons@University of Nebraska - Lincoln. It has been accepted for inclusion in Agronomy \& Horticulture -Faculty Publications by an authorized administrator of DigitalCommons@University of Nebraska - Lincoln. 


\section{Registration of RN582 Sorghum Germplasm Line}

RN582 sorghum [Sorghum bicolor (L.) Moench] germplasm line (Reg. no. GP-591, PI 628277) was developed jointly by the USDA-ARS and the Agricultural Research Division, Institute of Agriculture and Natural Resources, University of Nebraska, and was released in September 2001.

$\mathrm{RN} 582$ is an $\mathrm{S}_{6}$ selection from the cross $\left(\mathrm{RTx} 430 \mathrm{~ms}_{3} m s_{3} \times\right.$ E 35-1) $\times$ E 35-1. RTx430 was developed and released by the Texas Agricultural Experiment Station (Miller, 1984) and was provided to this project containing the nuclear male sterility gene $m s_{3}$ by A.B. Maunder in 1988. E 35-1 is an Ethiopian land race with white seed, tan necrotic plant color, 2-dwarf in height, late maturing, and was obtained from A. SotomayorRios in 1979. RN582 has tan necrotic plant color ( $\left.p p_{-}\right)$, white pericarp (_yy), thin mesocarp $(Z Z)$, normal $(W x W x)$ white endosperm, no testa $\left(b_{1} b_{1} \_\right)$, and juicy culms $(d d)$. RN582 has demonstrated high heterotic potential for grain yield with $10 \%$ higher yields when crossed to AWheatland than the check hybrid AWheatland $\times$ RTx430 over the $3-y r$ period 1998 to 2000 , and $20 \%$ higher yields when crossed to ATx631 than the white seed tan plant check hybrid ATx631 $\times$ RTx437 in 2001 (Table 1). RN582 is adapted to the northern portion of the U.S. grain sorghum producing region and will reach anthesis $5 \mathrm{~d}$ earlier than RTx430 in that environment. RN582 is a strong restorer of fertility in A1 cytoplasm. Fertility reaction in other cytoplasmic sterility systems is not known. Nuclear male sterility has not been observed in RN582. Performance data for RN582 and its hybrids collected in 1998, 1999, 2000, and 2001 at Ithaca, NE, are presented in Table 1.

RN582 is a source of tan necrotic plant color and white

Table 1. Descriptive data for RN582, AWheatland $\times$ RN582 and ATx631 $\times$ RN582 hybrids.

\begin{tabular}{|c|c|c|c|c|c|}
\hline & Days to anthesis $\dagger$ & Height & Seed set $\%$ & Test weight & Yield \\
\hline Inbreds§ & & cm & $\%$ & $\mathbf{k g ~ h L ^ { - 1 }}$ & $\mathrm{kg} \mathrm{ha}^{-1}$ \\
\hline RN582 & 82 & 96 & 100 & 63 & 6020 \\
\hline RTx430 & 87 & 133 & 90 & 50 & 4076 \\
\hline BWheatland (BTx399) & 71 & 104 & 80 & 59 & 5581 \\
\hline LSD 0.05 & 3 & 13 & 21 & 21 & 1693 \\
\hline \multicolumn{6}{|l|}{ Hybrids 1998-2000I } \\
\hline AWheatland × RN582 & 76 & 165 & 99 & 77 & 10849 \\
\hline AWheatland $\times \mathbf{R T} \times 430$ & 74 & 139 & 84 & 76 & 9845 \\
\hline LSD 0.05 & 1 & 4 & 11 & 4 & 627 \\
\hline \multicolumn{6}{|c|}{ Hybrids 2001\# (tan plant white seed) } \\
\hline ATx631 $\times$ RN582 & 77 & 150 & 100 & 56 & 6707 \\
\hline ATx631 $\times \mathbf{R T x 4 3 7}$ & 76 & 131 & 100 & 54 & 5576 \\
\hline LSD0.05 & 1 & 8 & - & 6 & 714 \\
\hline
\end{tabular}

$\dagger$ Days from planting to $\mathbf{5 0} \%$ anthesis.

$\$$ Percent self seed set under pollinating bag.

$\S$ Data for inbreds are from a randomized complete block design experiment with $n=22$ and four replications at 1999 at Ithaca, NE.

II Data for hybrids are means pooled over 3 yr from randomized complete block design experiments with four replications at Ithaca, NE, in 1998 ( $n=$ 44), $1999(n=44)$, and $2000(n=39)$.

\# Data for tan plant white seed hybrids are from a randomized complete block design experiment with four replications at Ithaca, NE, in 2001 $(n=30)$. 
seed color with demonstrated high heterotic potential that is adapted to the northern portion of the U.S. sorghum production region. It is suited for the production of high quality grain for feed or food.

Seed of RN582 will be maintained and distributed by the USDA-ARS, Wheat, Sorghum, and Forage Research Unit, Department of Agronomy and Horticulture, University of Nebraska, Lincoln, Nebraska 68583-0937, and will be provided without cost to each applicant on written request. Requests from outside the USA must be accompanied by an import permit. Genetic material of this release will be deposited in the National Plant Germplasm System where it will be available for research purposes, including development and commercialization of new variety/cultivar. It is requested that appropriate recognition be made if this germplasm contributes to the development of a new breeding line or variety/cultivar.

J.F. PEDERSEN* AND J.J. TOY

\section{References}

Miller, F.R. 1984. Registration of RTx430 sorghum parental line. Crop Sci. 24:1224.

USDA-ARS, Dep. of Agronomy, Univ. of Nebraska-Lincoln, Lincoln, NE 68583-0937. Joint contribution of the USDA-ARS and the Dep. of Agronomy, Univ. Of Nebraska-Lincoln, as Journal Series Paper No. 13555. Registration by CSSA. Accepted 30 June 2002. *Corresponding author (jfp@unlserve.unl.edu).

Published in Crop Sci. 43:441-442 (2003). 